\title{
TELAAH MITOS KONSUMSI KARBOHIDRAT PADA DIABETES MELITUS (DM) TIPE 2
}

\author{
Dida Nurul Huda ${ }^{1}$, Novitasari ${ }^{1}$, Susi Kartika Dewi ${ }^{1}$, Anung Ahadi Pradana ${ }^{1}$ \\ ${ }^{1}$ Program Studi S1 Keperawatan, STIKes Mitra Keluarga-Bekasi \\ Email korespondensi: didanurul31@gmail.com
}

Kata kunci: Diabetes Melitus, Konsumsi Karbohidrat pada DM, Mitos pada DM

\section{DOUBT/DIFFERENCE}

Benarkah konsumsi karbohidrat bisa menyebabkan DM tipe 2 yang diderita bertambah parah?

\section{DESCRIPTION}

Penyakit Tidak Menular (PTM) sering disebut silent killer karena PTM merupakan penyebab kematian tertinggi sebelum era pandemik. Menurut data Kementrian Kesehatan Republik Indonesia (2020), terdapat empat penyakit utama PTM yang menyebabkan 60\% kematian yaitu kardiovaskuler, penyakit paru obstruksi kronis, kanker, dan DM. Penderita PTM tidak hanya pada lanjut usia, tetapi remaja hingga dewasa pun cukup banyak di Indonesia. Hal ini menjadi ketakutan tersendiri bagi masyakarat setempat, salah satunya pada penderita DM.

DM telah diakui sebagai salah satu dari empat penyakit tidak menular utama yang menuntut perhatian segera dari semua pemegang kepentingan nasional secara global dalam upaya untuk mengatasi prevalensi dan komplikasi terkait. Penyakit ini dianggap sebagai 10 penyebab kematian teratas secara global, membunuh sekitar 1,6 juta orang di seluruh dunia dan dipandang sebagai faktor risiko tertinggi ketiga untuk kematian dini di Dunia (Oguntibeju, 2019). Faktor pendorong utama kondisi DM tipe 2 secara global antara lain kelebihan berat badan dan obesitas, gaya hidup menetap dan peningkatan konsumsi makanan tidak sehat yang mengandung daging merah dan daging olahan tingkat tinggi, biji-bijian olahan dan minuman manis (Zheng, Ley, \& $\mathrm{Hu}, 2018)$. Sebagian masyarakat Indonesia hanya mengetahui jika DM tipe 2 disebabkan karena mengonsumsi karbohidrat terlalu tinggi, sehingga penderita DM tipe 2 biasanya menghindari makanan yang mengandung karbohidrat. 


\section{DISSECTION}

DM adalah penyakit yang terjadi akibat gula darah naik sehingga terganggunya sistem metabolisme tubuh. Glukosa atau gula darah adalah bahan bakar utama yang digunakan untuk pembuat energi dalam tubuh. Bisa didapat dari zat makanan yaitu karbohidrat. Karbohidrat dipecah menjadi glukosa, kemudian disalurkan ke dalam sel-sel seluruh organ tubuh melalui insulin. Insulin adalah hormon yang dikeluarkan oleh pankreas dan berfungsi mengatur banyaknya jumlah glukosa dalam darah serta memindahkan glukosa ke dalam sel. Apabila hormon insulin mengalami gangguan, jumlah glukosa dalam darah jadi tidak terkontrol dan menumpuk, sehingga menyebabkan aliran darah menjadi lambat dan mengental. Hal ini terjadi karena banyaknya karbohidrat yang masuk, insulin pun menjadi kerja ekstra untuk memindahkan glukosa. Semakin keras kerja insulin, maka akan semakin menurun fungsinya. Glukosa dalam darah pun tidak bisa dipindahkan dan terjadilah DM tipe 2 (Kementrian Kesehatan Republik Indonesia, 2020).

Dalam beberapa kasus DM, tipe 2 mitos larangan konsumsi karbohidrat menjadi hal yang sering diperbincangkan. Penderita takut karbohidrat membuat penyakitnya semakin parah dan memilih tidak mengonsumsi sama sekali. Padahal, tanpa adanya karbohidrat tubuh menjadi lemas dan mudah letih. Penderita DM tipe 2 tetap boleh mengonsumsi karbohidrat, namun sesuai aturan diit yang telah ditentukan. Menurut P2PTM Kementrian Kesesehatan RI (2018), penderita DM tipe 2 harus menghindari konsumsi karbohidrat sederhana atau yang mudah diserap salah satunya adalah ice cream, bolu, susu kental manis, gula pasir, sirup, manisan, buah-buahan, gula jawa. Kalori yang dibutuhkan bagi penderita DM tipe 2 ditentukan berdasarkan usia, jenis kelamin, berat badan, tinggi badan dan aktivitas. Batasi pengkonsumsian karbohidrat kompleks seperti nasi, roti, jagung, kentang, dengan mengurangi jumlahnya dari kebiasaan sehari-hari. Oleh karena itu, petugas kesehatan perlu memberikan edukasi seputar diit DM tipe 2 pada penderita apabila sedang berobat atau menjalani konsultasi.

\section{DISCOVER}

DM telah menjadi epidemi yang meningkat pada abad terakhir, lebih mendesak dalam beberapa dekade terakhir dengan peningkatan eksponensial obesitas, dan telah menjadi salah satu penyebab utama kematian di seluruh dunia. Mengingat prevalensi yang signifikan, pasien tetap 
tidak menyadari perkembangan penyakit mereka yang muncul dari faktor risiko genetik dan metabolik. Dibandingkan dengan non-diabetes, mereka dengan DM tipe 2 membawa risiko kematian yang lebih tinggi dari penyakit kardiovaskular (CVD) di berbagai kelompok etnis dan jenis kelamin (Glovaci, Fan, \& Wong, 2019). Wulandari \& Kurnianingsih (2018) menyebutkan ada beberapa hal yang diketahui memiliki pengaruh terhadap peningkatan risiko DM tipe 2 diantaranya:

1. Usia, setiap peningkatan 1 tahun usia seseorang, maka risiko peningkatan kadar gula darahnya menjadi meningkat sebesar 0,831 skor Gula Darah Sewaktu (GDS).

2. Tingkat stres, setiap peningkatan 1 poin tingkat stres seseorang (diukur menggunakan format Depression, Anxiety, \& Stress Scale/ DASS) diketahui dapat meningkatan risiko peningkatan sebesar 1.636 skor GDS. Lebih lanjut disebutkan dalam riset Oguntibeju (2019) yang menemukan adanya hubungan yang kuat antara stres yang dialami seseorang dengan kadar gula darahnya, stres yang dialami seseorang dapat memicu munculnya peradangan kronis yang pada akhirnya dapat meningkatkan tingkat resistensi insulin dalam dirinya.

3. Diit tinggi karbohidrat, Konsumsi diit tinggi gula sebagaimana yang disampaikan oleh P2PTM Kementrian Kesehatan RI di atas juga dapat meningkatkan skor GDS sebesar 0,97 dalam 1 kali konsumsi. Riset yang dilakukan Riset yang dilakukan oleh Fitri R.I \& Wirawanni (2014) menunjukkan bahwa konsumsi karbohidrat memiliki hubungan dengan dengan kadar gula darah puasa dan gula darah 2 jam post-prandial. Lebih lanjut disebutkan bahwa kombinasi dari konsumsi karbohidrat, konsumsi total energi, konsumsi serat, dan frekuensi latihan jasmani secara bersama-sama mempengaruhi 69,7\% kadar gula darah puasa dan 71,3\% kadar gula darah 2 jam post-prandial.

Beberapa tanda gejala yang dapat muncul akibat kenaikan gula darah antara lain polidipsi, poliuria, polifagi, kelelahan, lemas, pandangan kabur, pusing, dan mual (Nugroho, 2015).

Beberapa mitos yang mungkin sering didengar oleh beberapa penderita diabetes, bahwa seseorang yang memiliki penyakit DM tipe 2 tidak boleh makan makanan yang mengandung karbohidrat, karena penderita berpikiran bahwa makan karbohidrat terutama nasi akan membuat glukosa menjadi tinggi di dalam darah. Hal tersebutlah yang dapat membuat penderita DM tipe 2 jutru akan mengalami komplikasi atau bahkan dapat memperburuk kondisinya.

Kenyataan yang sebenarnya adalah bahwa penderita DM tipe 2 juga sangat perlu yang namanya karbohidrat untuk energi bagi tubuh. Jika tidak mengkonsumsi karbohidrat atau bahkan tidak 
mengkonsumsi sama sekali akan membuat penderita DM tipe 2 mengalami hipoglikemi atau penurunan gula darah secara drastis, yang nanti akan timbul gejala seperti lelah, pusing, keringat dingin, kejang hingga penurunan kesadaran bahkan sampai mengancam nyawa jika tidak segera ditangani (Mansyur, 2018). Hal ini didukung oleh riset yang menyebutkan bahwa salah satu penyebab terjadinya penurunan gula darah secara drastis pada pasien DM tipe 2 adalah penggunaan obat antidiabetik yang berlebihan. Utamanya pada pasien pengguna insulin dan obat golongan sulfonilurea (Hsu et al., 2013). Selain itu, penyebab lain terjadinya hipoglikemia adalah jumlah makanan (karbohidrat) yang dikonsumsi tidak cukup (Mansyur, 2018). Lebih lanjut risiko komplikasi lain yang jauh lebih berbahaya di antara pasien dengan DM tipe 2 adalah komplikasi kardiovaskuler serta gagal ginjal yang dapat menjadi penyebab utama morbiditas dan mortalitas khususnya pada pasien di negara-negara Asia (Zheng dkk., 2018).

\section{DECISION}

Pemerintah telah melakukan beberapa langkah uapay pencegahan Penyakit-penyakit Tidak Menular, dimana salah satu upaya yang dilaksanakan melalui Gerakan Masyarakat Hidup Sehat (GERMAS) dengan harapan masyarakat dapat melakukan gaya hidup sehat (Kementrian Kesehatan Republik Indonesia, 2016). Gaya hidup sehat adalah cara hidup mengikuti arahan atau pesan kesehatan untuk mendapatkan hidup lebih sehat seperti makan-makan bergizi, hindari merokok, minum alkohol, jangan lupa untuk olahraga, istirahat yang cukup, memanajemen stress, dan kebiasaan lainnya yang dapat meningkatkan produktivitas tubuh.

Adapun beberapa langkah pencegahan tingkat keparahan kondisi DM tipe 2 yang dialami oleh pasien antara lain:

1. Pemberian informasi kesehatan, Bagi penderita DM tipe 2, perlunya mencari tahu informasi mengenai pola makan yang benar, bahan makanan apa yang harus dihindari dan dikonsumsi karena sangat berpengaruh untuk kesehatan kedepannya (Putra \& Mahmudiono, 2012). Masyarakat jangan terlalu percaya mitos sampai mengetahui kebenarannya, dimaan zaman sekarang mudah menyebarkan berita palsu tanpa mengaitkan sumber asli. Hal ini yang perlu pasien dan kelaurga waspadai demi kebaikan diri sendiri.

2. Modifikasi diet dan gaya hidup, pasien yang mengalami DM tipe 2 wajib untuk menjaga pola makan yang BUKAN berfokus pada mengurangi konsumsi karbohidrat, TAPI lebih berfokus pada pemilahan jenis karbohidrat yang akan dikonsumsi. Karbohidrat kompleks 
merupakan sumber karbohidrat dan serat yang baik bagi penderita DM tipe 2, hal ini didukung oleh riset yang dilakukan oleh Zheng dkk. (2018) yang menyebutkan bahwa modifikasi diet dan gaya hidup memiliki tingkat efektivitas pada individu yang memiliki DM tipe 2. Selain itu, pola diit yang tinggi konsumsi bahan makanan sumber dietary fiber seperti whole grain, oatmeal, roti gandum dan lain-lain memiliki efek positif dalam menurunkan kadar gula darah secara bertahap (Putra \& Mahmudiono, 2012; Rusdi, 2020). Riset lain menunjukkan bahwa Diet rendah karbohidrat, pembatasan kalori, dan kontrol energi dapat menurunkan faktor risiko komplikasi serta meningkatkan kepuasan selama menjalani perawatan pada pasien DM tipe 2 (Kurnia, 2019).

3. Self-Monitoring, self monitoring gula darah yaitu dimana penderita DM tipe 2 dapat melakukan pengecekan glukosa darah secara mandiri dirumah dengan menggunakan alat cek gula darah dengan menusukan darah pada bagian ujung jari penderita, selain itu pengendalian yang bisa dilakukan pada penderita DM tipe 2 yaitu membiasakan membawa permen atau tablet glukosa yang siap dimakan sewaktu-waktu bila terjadi hipoglikemia (Seligman, Davis, Schillinger, \& Wolf, 2010).

4. Dukungan sosial, Dukungan sosial diperlukan untuk tetap menjaga semangat dan kepatuhan pasien DM tipe 2 dalam melakukan pengobatan sehari-hari mengingat DM tipe 2 adalah penyakit seumur hidup yang membutuhkan keteguhan dari pasien (Zheng dkk., 2018).

\section{UCAPAN TERIMAKASIH}

Kami ucapkan terimakasih kepada dosen pembimbing kami yaitu Bapak Ns. Anung Ahadi Pradana, M.Kep., Sp.Kep.Kom yang sudah bersedia membimbing dan membantu kami dalam penulisan naskah esai ini.

\section{DAFTAR PUSTAKA}

Fitri R.I, \& Wirawanni, Y. (2014). HUBUNGAN KONSUMSI KARBOHIDRAT, KONSUMSI TOTAL ENERGI, KONSUMSI SERAT, BEBAN GLIKEMIK DAN LATIHAN JASMANI DENGAN KADAR GLUKOSA DARAH PADA PASIEN DIABETES MELLITUS TIPE 2. Diponegoro Journal of Nutrition and Health, 2(3), 1-27. https://doi.org/https://www.neliti.com/publications/89842/hubungan-konsumsi-karbohidratkonsumsi-total-energi-konsumsi-serat-beban-glikemi 
Glovaci, D., Fan, W., \& Wong, N. D. (2019). Epidemiology of Diabetes Mellitus and Cardiovascular Disease. Current Cardiology Report, 21(21). https://doi.org/10.1007/s11886-019-1107-y

Hsu, P. F., Sung, S. H., Cheng, H. M., Yeh, J. S., Liu, W. L., Chan, W. L., ... Chuang, S. Y. (2013). Association of clinical symptomatic hypoglycemia with cardiovascular events and total mortality in type 2 diabetes: A nationwide population-based study. Diabetes Care, 36(4), 894-900. https://doi.org/10.2337/dc12-0916

Kementrian Kesehatan Republik Indonesia. (2016). PERATURAN MENTERI KESEHATAN REPUBLIK INDONESIA NOMOR 25 TAHUN 2016 TENTANG RENCANA AKSI NASIONAL KESEHATAN LANJUT USIA TAHUN 2016-2019. Jakarta. Retrieved from http://www.kesmas.kemkes.go.id/assets/upload/dir_519d41d8cd98f00/files/PMK-No.-25Tahun-2016-ttg-Rencana-Aksi-Nasional-Kesehatan-Lanjut-Usia-Tahun-2016-2019_867.pdf Kementrian Kesehatan Republik Indonesia. (2020). Penyakit Tidak Menular (PTM). Retrieved March 19, 2021, from http://p2ptm.kemkes.go.id/informasi-p2ptm/penyakit-diabetesmelitus

Kurnia, A. (2019). Diet rendah karbohidrat pada pasien diabetes mellitus tipe 2: Literature review. NURSCOPE: Jurnal Penelitian Dan Pemikiran Ilmiah Keperawatan, 5(2), 46-52. https://doi.org/10.30659/nurscope.5.2.46-52

Mansyur, A. M. A. (2018). Hipoglikemia dalam Praktik Sehari-hari. Departemen Ilmu Penyakit Dalam.

Nugroho, S. (2015). Pencegahan Dan Pengendalian Diabetes Melitus Melalui Olahraga. Medikora, IX(1). https://doi.org/10.21831/medikora.v0i1.4640

Oguntibeju, O. O. (2019). Type 2 diabetes mellitus, oxidative stress and inflammation: examining the links. International Journal of Physiology, Pathopysiology, and Pharmacology, 11(3), 45-63. $\quad$ Retrieved from https://www.ncbi.nlm.nih.gov/pmc/articles/PMC6628012/

P2PTM Kemenkes RI. (2018). Diet pada Diabetes Mellitus.

Putra, F. D., \& Mahmudiono, T. (2012). HUBUNGAN TINGKAT KONSUMSI KARBOHIDRAT, LEMAK, DAN DIETARY FIBER DENGAN KADAR GULA DARAH PADA PENDERITA DIABETES MELLITUS TIPE 2. Media Gizi Indonesia, 2(9), 15281238. Retrieved from http://repository.unp.ac.id/494/1/WILDA WELIS 
hemoglobin.pdf\#page $=75$

Rusdi, M. S. (2020). Hipoglikemia Pada Pasien Diabetes Melitus. Journal Syifa Sciences and Clinical Research, 2(2), 83-90.

Seligman, H. K., Davis, T. C., Schillinger, D., \& Wolf, M. S. (2010). Food insecurity is associated with Hypoglycemia and poor diabetes self-management in a low-income sample with diabetes. Journal of Health Care for the Poor and Underserved, 21(4), 1227-1233. https://doi.org/10.1353/hpu.2010.0921

Wulandari, D., \& Kurnianingsih, W. (2018). Pengaruh usia, stres, dan diet tinggi karbohidrat terhadap kadar glukosa darah. INFOKES, 8(1), 16-25. https://doi.org/10.47701/infokes.v8i1.192

Zheng, Y., Ley, S. H., \& Hu, F. B. (2018). Global aetiology and epidemiology of type 2 diabetes mellitus and its complications. Nature Reviews Endocrinology, 14(1), 88-98. https://doi.org/10.1038/nrendo.2017.151 